\title{
SUPPLIER SELECTION USING A HYBRID MODEL FOR 3C INDUSTRY
}

\author{
Kwo-Liang CHEN ${ }^{1}$, Ching-Chiang YEH ${ }^{2}$, Jo-Chen HUANG ${ }^{3}$ \\ ${ }^{1}$ Department of Industrial Engineering and Management, China University \\ of Science and Technology, No.245, Sec. 3, Academia Rd., \\ Nangang Dist., Taipei City, Taiwan 115, R.O.C. \\ ${ }^{2}$ Department of Business Administration, National Taipei University of Business, \\ No.321, Sec. 1, Jinan Rd., Zhongzheng District, Taipei, 100, Taiwan, R.O.C. \\ ${ }^{3}$ Graduate Institute of Business Administration, Soochow University, \\ No.56. Kueiyang Street, Section 1, Taipei, Taiwan 100, R.O.C. \\ Emails: 19lchen@moeasmea.gov.tw; 2ychinc@ntub.edu.tw (correspondingauthor); \\ 3tzu626@hotmail.com
}

Received 31 March 2013; accepted 20 May 2013

\begin{abstract}
Supplier selection is a good strategy for firms that can reduce operating costs and improve competitiveness for computer, communication and consumer electronics (3C) industry. The major aim of this research is to build a systematic approach for establishing a supplier selection model, and then prioritize improvement criteria in order to best supply chain management. The study proposed a hybrid approach by using the interpretive structural modeling (ISM) method to deal with the interrelationship among criteria, and the analytic network process (ANP) method is employed to recognize the criteria of supplier selection and evaluate with respect to environmental competency for the case of Taiwan's $3 \mathrm{C}$ industry. The study shows that the proposed model could be an effective and efficient decision-making tool that can be easily extended to other contexts. Especially, it has provided decision-makers and researchers with better understanding of the differences in supplier selection activity needs and specific management interventions by examining these criteria.
\end{abstract}

Keywords: supplier selection, interpretive structural modeling, analytic network process, hybrid model, $3 \mathrm{C}$ industry, Taiwan.

JEL Classification: C02, C44, C86, L10, M11, O11.

\section{Introduction}

Supplier selection decisions affect various functional areas from procurement of raw materials and components to production and delivery of the end products. Selecting appropriate suppliers will significantly reduce the costs of purchasing materials and improve competitive conditions. For this reason, supplier selection problem has been gaining attention in both academic literature and industrial practice. 
Supplier selection has been treated as a multi-criteria decision making (MCDM) problem and a wide range of mathematical methods have been undertaken to provide the problems (Agarwal et al. 2011; Boer et al. 2001; Ho et al. 2010; Ku et al. 2010; Liou et al. 2011). Nevertheless, some have striven to apply the MCDM method to different supplier selection issues, but have assumed the criteria to be independent. It is usually using the analytic hierarchical process (AHP) to construct a model of the supplier selection problems, some main problems should be highlighted as follows. Firstly, in the real world, different criteria are seldom independent and always have a degree of interactive relationships, sometimes with dependence and feedback effects (Tsai, Chou 2009; Tzeng et al. 2007). Secondly, given growing environmental concerns during the past decade, a consensus is emerging that environmental pollution issues accompanying industrial development should be addressed together with supplier selection. Despite the growing importance of environmental issues for supplier in the supplier selection (Lamming, Hampson 1996; Rao 2002; Srivastava 2007), it is usually excluded from earlier studies.

In view of the significance of incorporating the environmental issues into supplier selection as well as the limitation of previous studies, the motivation of the study aim to build a systematic approach for establishing a supplier selection model, and then prioritize improvement criteria in order to best supply chain management. To achieve this goal, we use the interpretive structural modeling (ISM) method to deal with the interrelationship among criteria, and the analytic network process (ANP) method (which releases the restriction of the hierarchical structure) is employed to recognize the criteria of supplier selection and evaluate with respect to environmental competency in supplier selection. Therefore, two methods are incorporated in this study. First, we construct the relation map obtained from ISM which can help the user visualize the complex relationships among the criteria. Second, based on the results of the relation map we consider the interdependence and feedback effect between criteria by applying the ANP. Data from a Taiwan's computer, communication and consumer electronics (3C) industry is used to demonstrate this model. This generic model can be easily extended to other industries, to provide some useful information to decision makers or managers for their referential purposes.

The remainder of this paper is organized as follows. In the following section, the related researches of supplier selection criteria are reviewed. The section 2 presents the methods of this study, the ISM and ANP. The section 3 illustrates an empirical case study taking the Taiwanese $3 \mathrm{C}$ industry as an example used to validate our model. Discussion and findings are provided in the fourth section. The paper ends with some important managerial implications and suggestions for further research.

\section{The evaluating criteria for supplier selection}

Choosing criteria is a fundamental section in a decision-making model, especially in supplier selection. A number of research works published in the last decades have addressed a variety of criteria that are important in supplier selection. The analysis of such criteria for the selection, measuring the performances of potential suppliers and 
the introduction of a new categories of selection criteria following the market evolutions have been the focus of many researchers and practitioners.

According to the previous studies, various organizations select their suppliers through different criteria across different periods of time and environments. Unlike, the other researchers, we list some of these criteria by types of firms in Table 1.

Table 1. Applications of selected criteria/ sub-criteria for vendor evaluation

\begin{tabular}{|c|c|c|}
\hline Type of firms & Criteria/ sub-criteria & References \\
\hline Baby food manufacturer & Price, quality, delivery. & Weber (1996) \\
\hline Bicycle manufacturer & $\begin{array}{l}\text { Quality, delivery, price, facility, technical } \\
\text { capability, financial position, past } \\
\text { performance attitude, flexibility, service. }\end{array}$ & $\begin{array}{l}\text { Muralidharan } \\
\text { et al. (2002) }\end{array}$ \\
\hline $\begin{array}{l}\text { Bottling machinery } \\
\text { industry }\end{array}$ & $\begin{array}{l}\text { Product price, shipment quality, delivery } \\
\text { compliance. }\end{array}$ & $\begin{array}{l}\text { Petroni and Braglia } \\
(2000)\end{array}$ \\
\hline $\begin{array}{l}\text { Equipment } \\
\text { manufacturer }\end{array}$ & $\begin{array}{l}\text { Acquisition costs, product quality, delivery } \\
\text { reliability. }\end{array}$ & Karpak et al. (2001) \\
\hline $\begin{array}{l}\text { Public road and rail } \\
\text { transportation }\end{array}$ & $\begin{array}{l}\text { Make-up, processing time, prototyping } \\
\text { time, design revision time, quality system, } \\
\text { co-design, technological level. }\end{array}$ & $\begin{array}{l}\text { Dulmin and Mininno } \\
\text { (2002) }\end{array}$ \\
\hline $\begin{array}{l}\text { Telecommunications } \\
\text { company }\end{array}$ & $\begin{array}{l}\text { Cost (capital expenditure, operating } \\
\text { expenditure), quality (technical, operational, } \\
\text { vendor). }\end{array}$ & $\begin{array}{l}\text { Tam and Tummala } \\
\text { (2001) }\end{array}$ \\
\hline Wafer-testing & $\begin{array}{l}\text { Delivery management capability, quality } \\
\text { management capability, integrated service } \\
\text { capability, price. }\end{array}$ & Lin et al. (2010) \\
\hline Airline industry & Compatibility, risk, quality, cost. & Liou et al. (2011) \\
\hline Automotive industry & $\begin{array}{l}\text { Delivery, quality, price, transportation cost, } \\
\text { technology, production system flexibility. }\end{array}$ & $\begin{array}{l}\text { Golmohammadi and } \\
\text { Mellat-Parast (2012) }\end{array}$ \\
\hline Watch manufacturer & $\begin{array}{l}\text { Relationship closeness, quality of product, } \\
\text { delivery capabilities, warranty level, } \\
\text { experience time. }\end{array}$ & Liao and Kao (2011) \\
\hline $\begin{array}{l}\text { Irrigation equipment } \\
\text { industry }\end{array}$ & $\begin{array}{l}\text { Strategic operational performance, } \\
\text { Organizational factor, environmental factor. }\end{array}$ & Dou et al. (2013) \\
\hline
\end{tabular}

In summary, the existing literature is very rich with the criteria of supplier selection, we conclude there are no universal or exact criteria for supplier selection; thus, supplier selection mean different things for different industries. It seems to suggest that the concept of supplier selection is context-dependent, and its evaluation should reflect the industry environment being investigated. The proposed methodology for supplier selection and how to extract the evaluating criteria in the Taiwan's 3C industry are briefly described in the subsequent sections. 


\section{Methodology}

In this section, we introduce the concepts of the ISM and ANP methods, respectively.

\subsection{Interpretive structural modeling}

Interpretive structural modeling (ISM), proposed by Warfield (1974a), is based on discrete mathematics, graph theory, social sciences, group decision- making, and computer assistance (Warfield 1974a; 1974b; 1976). The procedures of the binary matrix manipulation of ISM are illustrated as follows:

(1) List criteria (sub-criteria) considered for the problem, and define each criterion (subcriterion) as $e_{\mathrm{i}}, i=1,2,3, \ldots, n$.

(2) Formation of incidence matrix. From the criteria (sub-criteria) identified in step 1, establish adjacency (relation) matrix which shows the relationship among the criteria (sub-criteria). Let $e_{i}$ be the $i$ th criterion, and $\pi_{i j}$ be the interrelationship between $i^{\text {th }}$ and $j^{\text {th }}$ criteria. The adjacency matrix is then developed based on a pair-wise comparison of variables. Moreover, the adjacency matrix is formed by asking questions such as, "Will element $e_{i}$ affect element $e_{j}$ ?". If the answer is yes, then $\pi_{i j}=1$. If the answer is no, then $\pi_{i j}=0$. The adjacency matrix is an $n \times n$ matrix $\boldsymbol{A}=\left[\pi_{i j}\right]$ can be described as follows:

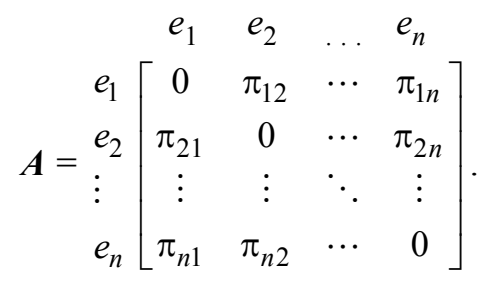

(3) Deduction of reachability matrix. The reachability matrix $R=\left[r_{i j}\right]$ is the limit of the Boolean $n$-multiple product of $A+I$, where $I$ is a Boolean unity matrix, and "+" is addition in Boolean sense. The reachability matrix $R$ represents all linkages between system variables. The entry $r_{i j}=1$ indicates that variable $e_{j}$ is under the direct or indirect influence of variable $e_{i}$, or it is said that variable $e_{j}$ is reachable by variable $e_{i}$ if $r_{i j}=1$. (4) Construction of system levels. The "entry level" of a system is a set of variables that cannot be reached by any variables in other sets. All system levels could be identified one by one using a recursive algorithm that excludes the current "entry level" from consideration in the next round after it is identified. The final reachability matrix $R^{*}$ provides a basic guideline when establishing the system structure.

The main benefits of the ISM methodology is that it transforms unclear and poorly articulated models of systems into visible and well-defined models (Sage 1977). Therefore, we can simply plot the network structure based on the adjacency matrix and reachability matrix to construct the relationships of all the criteria and sub-criteria.

\subsection{ANP}

The ANP is a generalization of the Analytic Hierarchy Process (AHP) (Saaty 1996). The AHP, also developed by Saaty (1980), is one of the most widely used MCDM methods. However, the AHP method has some fallible premises with the assumption 
that the criteria are independent (Satty 1996). The ANP extends the AHP to problems with dependence and feedback. It allows for more complex interrelationships among decision elements by replacing a hierarchy in the AHP with a network (Saaty 2009).

ANP uses a "supermatrix" to obtain the composite weight to deal with the relationship of feedback and interdependence among the criteria. If no interdependent relationship exists among the criteria, then the pairwise comparison value would be 0 . If an interdependent and feedback relationship exists among the criteria, then such value would no longer be 0 , and an unweighted supermatrix $W$ would be obtained. If the matrix does not conform to the principle of column stochastic, the decision-maker can provide the weights to adjust it into a supermatrix that conforms to the principle of column stochastic. It will then become a weighted supermatrix $W$. Then, the limited weighted supermatrix $W^{*}$ is obtained based on Eq. (2), and the gradual convergence of the interdependence relationship results in the obtaining the accurate relative weights among the criteria:

$$
W^{*}=\lim _{k \rightarrow \infty} W^{k}
$$

Moreover, the ANP is the mathematical theory that can deal with all kinds of dependences systematically. Recently, there has been a huge increase in the use of the ANP in a variety of decision making problems (S. Chen, R. Chen 1998; Tjader et al. 2013; Hsu et al. 2013). In the supplier selection problem, some criteria may have some interdependencies and cannot be captured by the AHP method. Therefore, we use the ANP method instead of the popular AHP approach to the supplier selection model for Taiwan's 3C industry.

\subsection{Proposed approach}

For supplier selection problem, some criteria may have dependent or feedback relationships. It may distort the actual results if we assume the independence among the criteria. Hence, this study proposed a hybrid model, integrating ISM and ANP to solve supplier selection problem considering environment factors, as follows.

Step 1: Problem description. The first step is to define the service evaluation problem. Moreover, an expert team is formed that not only replies to the questionnaires to construct the evaluation and selection model but also provides professional knowledge based on experience in the service industry.

Step 2: Establishing supplier selection criteria. In the step, the criteria and sub-criteria suitable to evaluate the supplier selection are selected.

Step 3: Using ISM to analyze the interrelationships among the criteria and sub-criteria. In this step, the interrelationships among the criteria in the evaluation model are constructed by applying the ISM method so that a structural network relationship map and the reachability matrix can be constructed accordingly.

Step 4: Utilizing ANP to calculate the relative weight for each criterion and sub-criterion. The ANP is then utilized to derive the weightings based on these interrelationships and the network relationship map from the ISM step. The final step is to determine the limiting the weighted supermatrix for the weight and calculating the weights of all criteria and sub- criteria. 


\section{Empirical analysis}

In this section, an empirical case of the supplier selection for Taiwan's 3C industry is used to illustrate the feasibility of the proposed approach.

\subsection{Problem descriptions}

The 3C industry in Taiwan, mainly OEM/ODM, is closely related to oversea big electronic companies, holds a significant position in the design, manufacturing and assembly in the global supply chain. The $3 \mathrm{C}$ firms need to outsource most of their component to subcontractors and therefore the supplier evaluation and selection is crucial. Therefore, we take a case from Taiwan's 3C industry to demonstrate the proposed approach.

The model is developed and then validated using data from the expert team, which contained 20 experts with extensive experience consulting in this study. Among the 20 experts, 10 were from the computer manufacturer, 5 were from the communication manufacturer, and the remaining 5 were from the consumer-electronics manufacturer. The average industry experience of the experts was about six years. Although this study did not have a large number of experts, they also provided their professional knowledge and experience in $3 \mathrm{C}$ and supplier management, along with an industrial perspective. Moreover, they also replied to the questionnaires for constructing this evaluation and selection model.

\subsection{Establishing supplier selection criteria}

The supplier selection criteria were developed on the basis of a literature review and a series of discussions with expert team. This discussion with the expert team helped us to classify the various criteria of decision-making into five criteria are most suitable. The five criteria include: (1) Flexible capability (F); (2) Quality capability (Q); (3) Technological capability (T); (4) Environmental management capability (E); and (5) Service capability (S). These criteria were then divided into various sub-criteria, as indicated in Table 2. Because these relevant criteria are summarized on the basis of associated work and consulted by expert team, it can have relatively high content validity and face validity.

\subsection{Using ISM to analyze the interrelationships among criteria and sub-criteria}

Since the supplier selection is complex, it is not appropriate to assume the elements within selection process are independent. Therefore, we sought to find the important criteria for the various criteria and measure the relationships among these criteria. Experts were asked to score the relationships among criteria and among sub-criteria following the ISM procedures described in methodology. The geometric mean of experts' opinions on the relationship between a pair of criteria (sub-criteria) was calculated. The original interrelationships data amongst all the criteria are listed in Table 3.

Setting the threshold value $=0.50$ which represents that more than $50 \%$ of the experts determine the interrelationship is existent. If the value of the element inside the matrix is $>0.50$, the value is counted as 1 . If the value of the element is $<0.50$, the value is counted as 0 . Then the interrelationships matrix $(\boldsymbol{A})$ could be gained, and the matrix $(\mathrm{R})$ could be gained, by using Eq. (1), as shown in Tables 4 and 5 . 
Table 2. The criteria and sub-criteria for supplier selection

\begin{tabular}{|c|c|c|}
\hline Criteria & Sub-criteria & References \\
\hline \multirow[t]{4}{*}{$\begin{array}{l}\text { Flexible } \\
\text { capability }(F)\end{array}$} & Product flexibility (F1) & $\begin{array}{l}\text { Gosling et al. (2010); Ndubisi } \\
\text { et al. (2005) }\end{array}$ \\
\hline & Process flexibility (F2) & Gosling et al. (2010) \\
\hline & Delivery flexibility (F3) & Gosling et al. (2010) \\
\hline & Capacity flexibility (F4) & $\begin{array}{l}\text { Gosling et al. (2010); } \\
\text { Ndubisi et al. (2005) }\end{array}$ \\
\hline \multirow{3}{*}{$\begin{array}{l}\text { Quality } \\
\text { capability (Q) }\end{array}$} & Product quality (Q1) & Chen, Lin and Huang (2006) \\
\hline & Manufacturing process control ability (Q2) & Evans and Johnson (2005) \\
\hline & Archive of quality records (Q3) & Evans and Johnson (2005) \\
\hline \multirow[t]{3}{*}{$\begin{array}{l}\text { Technological } \\
\text { capability }(\mathrm{T})\end{array}$} & Entrepreneurial innovation capability (T1) & $\begin{array}{l}\text { Wagner (2009), Schiele } \\
\text { (2006) }\end{array}$ \\
\hline & Technical support / expertise (T2) & Tam and Tummala (2001) \\
\hline & Production capability (T3) & $\begin{array}{l}\text { Weber, Current and Benton } \\
\text { (1991) }\end{array}$ \\
\hline \multirow{3}{*}{$\begin{array}{l}\text { Environmental } \\
\text { management } \\
\text { capability (E) }\end{array}$} & Environmental protection policy (E1) & $\begin{array}{l}\text { Handfield et al. (2002); } \\
\text { Humphreys et al. (2003) }\end{array}$ \\
\hline & $\begin{array}{l}\text { Research and develop environment friendly } \\
\text { materials (E2) }\end{array}$ & Humphreys et al. (2003) \\
\hline & Product recycle/reuse/recovery (E3) & $\begin{array}{l}\text { Handfield et al. (2002), } \\
\text { Humphreys et al. (2003) }\end{array}$ \\
\hline \multirow[t]{3}{*}{$\begin{array}{l}\text { Service } \\
\text { capability (S) }\end{array}$} & Conflict / problem solving capability (S1) & $\begin{array}{l}\text { Chen, Lin and Huang (2006), } \\
\text { Lin and Chang (2008) }\end{array}$ \\
\hline & After-sales service (S2) & Tam and Tummala (2001) \\
\hline & Relationship closeness (S3) & $\begin{array}{l}\text { Chen, Lin and Huang (2006), } \\
\text { Lin and Chang (2008) }\end{array}$ \\
\hline
\end{tabular}

Table 3. Original interrelation matrix

\begin{tabular}{lccccc}
\hline \multicolumn{1}{c}{ Criteria } & F & Q & T & E & S \\
\hline Flexible capability (F) & 0.00 & 0.55 & 0.88 & 0.40 & 0.95 \\
\hline Quality capability (Q) & 0.88 & 0.00 & 1.00 & 0.45 & 0.85 \\
\hline Technological capability (T) & 0.58 & 0.63 & 0.00 & 0.33 & 0.50 \\
\hline Environmental management capability (E) & 0.15 & 0.45 & 0.48 & 0.00 & 0.40 \\
\hline Service capability (S) & 0.87 & 0.63 & 0.70 & 0.10 & 0.00 \\
\hline
\end{tabular}


Finally, the reachability matrix can be obtained by using Eq. (2). The star (*) indicates the derivative relationship, which did not emerge in the original relation matrix. The correlations of each criterion are shown as Table 6 and Figure 1.

Table 4. Interrelation matrix $(A)$

\begin{tabular}{lccccc}
\hline \multicolumn{1}{c}{ Criteria } & $\mathrm{F}$ & $\mathrm{Q}$ & $\mathrm{T}$ & $\mathrm{E}$ & $\mathrm{S}$ \\
\hline Flexible capability (F) & 0.00 & 1.00 & 1.00 & 0.00 & 1.00 \\
\hline Quality capability (Q) & 1.00 & 0.00 & 1.00 & 0.00 & 1.00 \\
\hline Technological capability (T) & 1.00 & 1.00 & 0.00 & 0.00 & 1.00 \\
\hline Environmental management capability (E) & 0.00 & 0.00 & 0.00 & 0.00 & 0.00 \\
\hline Service capability (S) & 1.00 & 1.00 & 1.00 & 0.00 & 0.00 \\
\hline
\end{tabular}

Table 5. Matrix $(R)$ of all criteria

\begin{tabular}{lccccc}
\hline \multicolumn{1}{c}{ Criteria } & F & Q & T & E & S \\
\hline Flexible capability (F) & 1.00 & 1.00 & 1.00 & 0.00 & 1.00 \\
\hline Quality capability (Q) & 1.00 & 1.00 & 1.00 & 0.00 & 1.00 \\
\hline Technological capability (T) & 1.00 & 1.00 & 1.00 & 0.00 & 1.00 \\
\hline Environmental management capability (E) & 0.00 & 0.00 & 0.00 & 1.00 & 0.00 \\
\hline Service capability (S) & 1.00 & 1.00 & 1.00 & 0.00 & 1.00 \\
\hline
\end{tabular}

Table 6. Reachability matrix $\left(R^{*}\right)$ of all criteria

\begin{tabular}{lccccc}
\hline \multicolumn{1}{c}{ Criteria } & $\mathrm{F}$ & $\mathrm{Q}$ & $\mathrm{T}$ & $\mathrm{E}$ & $\mathrm{S}$ \\
\hline Flexible capability (F) & 1.00 & 1.00 & 1.00 & 0.00 & 1.00 \\
\hline Quality capability (Q) & $1.00^{*}$ & 1.00 & 1.00 & 0.00 & 1.00 \\
\hline Technological capability (T) & 1.00 & 1.00 & 1.00 & 0.00 & 1.00 \\
\hline Environmental management capability (E) & 0.00 & 0.00 & 0.00 & 1.00 & 0.00 \\
\hline Service capability (S) & $1.00^{*}$ & 1.00 & $1.00^{*}$ & 0.00 & 1.00 \\
\hline
\end{tabular}

Based on $R^{*}$, the interrelationship among the five criteria can be depicted as in Figure 1. According to the experts' opinions through ISM analysis, Quality capability (Q), Flexible capability (F), Technological capability (T) and Service capability (S) were mutually interrelated. This can be seen from the double-sided arrows among the four criteria in Fig. 1. For example, while Quality capability (Q) had an effect on Flexible capability (F), Technological capability (T) and Service capability (S), the criterion was also affected by these three criteria. Such kind of interrelationships also applied to the other three criteria Flexible capability (F), Technological capability (T) and Service capability (S). Also note that Environmental management capability (E) was independent from other criteria. Such an outcome might seem to be surprising, but it was generated 


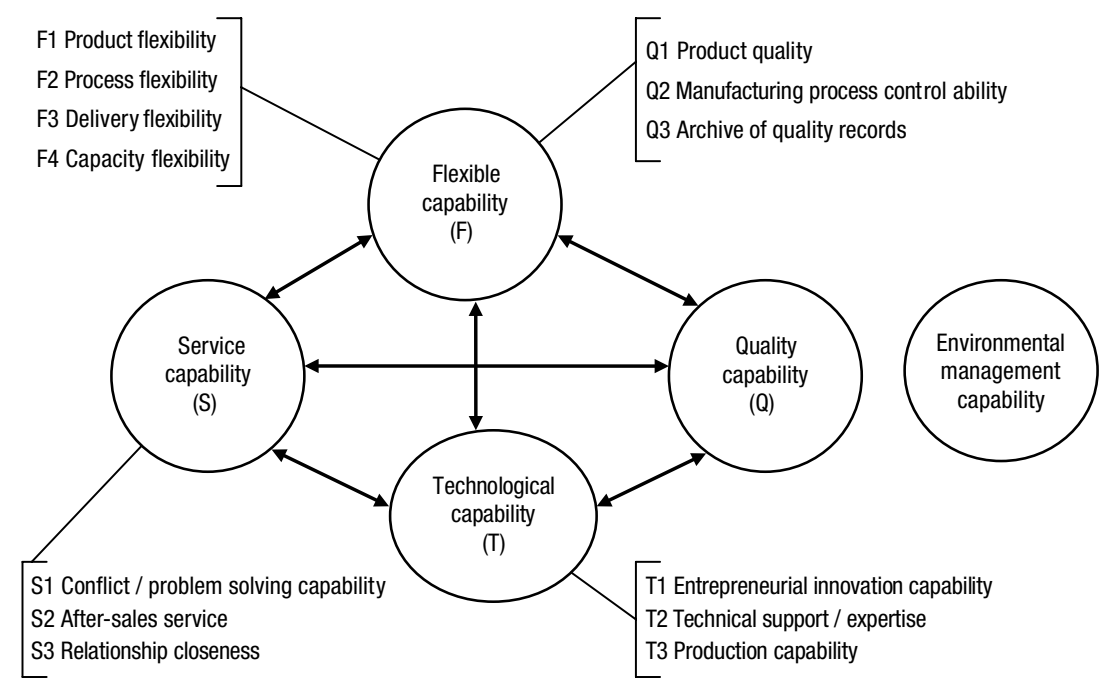

Fig. 1. ANP networked evaluation structure for supplier selection

from the experts' opinions through ISM. The result was double-confirmed after the network was formed. A possible reason behind could be that the interrelationship among Environmental management capability and other criteria were not very significant, and thus could be neglected in the criteria level.

\subsection{Utilizing ANP to calculate the relative weight for each criterion and sub-criterion}

After the previous stage which uses ISM to analyze the interrelationships among the criteria and setting up networked level evaluation structure is done, in the stage, ANP professional questionnaire is developed based on the previous stage. In this research, the opinions of experts were collected and then entered into ANP software of Super Decision to obtain the relative weights of each sub-criterion of each evaluation criteria. Based on the relationship of the four main criteria (see Fig. 1), aiming the sub-criteria belongs to each criteria designing ANP questionnaire, as well as using geometric mean from the experts' opinions to construct a pairwise comparison matrix. An unweighted supermatrix, a weighted supermatrix, and eventually a converged limiting supermatrix (see Table 7) are obtained by introducing pairwise comparison values of sub-criteria in the matrix into ANP software of Super Decision. Then the relative weights of four criteria and sub-criteria are collected (see Table 8).

As illustrated in Table 8, all the consistency ratio (CR) values are less than 0.1 , indicating consistency (Saaty 1980). It also could be seen from Table 8 that Quality capability (Q) (0.3799) is the one valued the most in the 3C industry, followed closely by Technological capability (T) (0.26551), Flexible capability (F) (0.23215) and Service capability (S) (0.1214) come after in the sequence of four criteria. Moreover, we make a ranking for each sub-criterion in each criterion which indicates the degree of importance from the questionnaire collection. These priorities of the sub-criteria also are listed in Table 8 . 


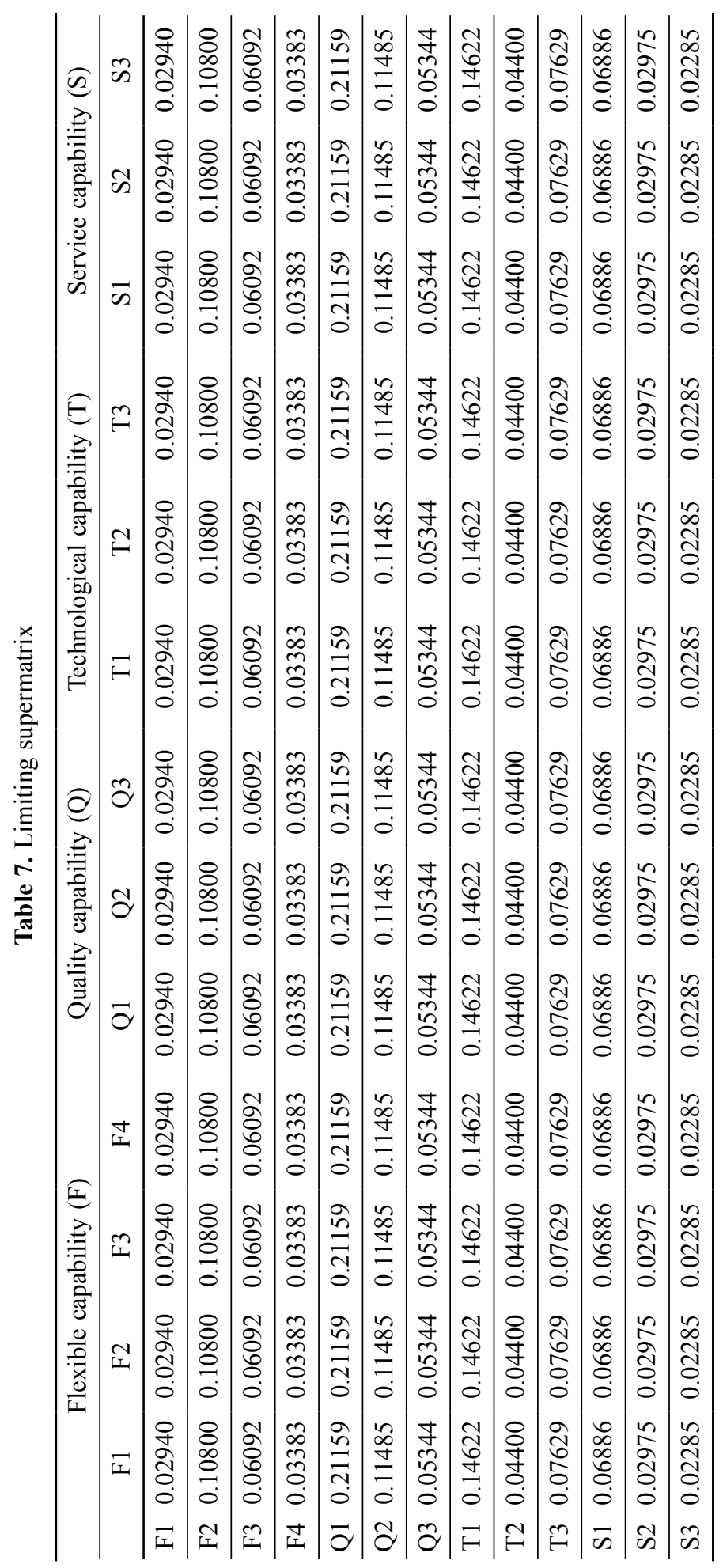


Table 8. Relative weights of criteria / sub-criteria

\begin{tabular}{ll}
\hline \multicolumn{1}{c}{ Criteria / sub-criteria } & Relative weight (ranking) \\
\hline Flexible capability (F) (CR $=0.01)$ & $0.23215(3)$ \\
\hline Product flexibility (F1) & $0.12663(4)$ \\
\hline Process flexibility (F2) & $0.46522(1)$ \\
\hline Delivery flexibility (F3) & $0.26241(2)$ \\
\hline Capacity flexibility (F4) & $0.14574(3)$ \\
\hline Quality capability (Q) (CR $=0.07)$ & $0.37988(1)$ \\
\hline Product quality (Q1) & $0.55700(1)$ \\
\hline Manufacturing process control ability (Q2) & $0.30232(2)$ \\
\hline Archive of quality records (Q3) & $0.14068(3)$ \\
\hline Technological capability (T) (CR $=0.03)$ & $0.26651(2)$ \\
\hline Entrepreneurial innovation capability (T1) & $0.54865(1)$ \\
\hline Technical support / expertise (T2) & $0.16511(3)$ \\
\hline Production capability (T3) & $0.28624(2)$ \\
\hline Service capability (S) (CR =0.02) & $0.1214(4)$ \\
\hline Conflict / problem solving capability (S1) & $0.56692(1)$ \\
\hline After-sales service (S2) & $0.24494(2)$ \\
\hline Relationship closeness (S3) & $0.18814(3)$ \\
\hline
\end{tabular}

In the Flexible capability category, the Process flexibility (F2) (0.46522) was rated as the most important criterion; in Quality capability, Product quality (Q1) (0.55700) was rated as the most important; in Technological capability, Entrepreneurial innovation capability (T1) (0.54865) was rated as the most important; and in Service capability, Conflict / problem solving capability (S1) (0.56692) was rated as the most important. After calculated all the weightings in the evaluation model through the ANP method, the completed Taiwan's $3 \mathrm{C}$ industry supplier selection model can be fully established.

\section{Discussion and findings}

This study not only uses ANP to find out the relative importance between criteria, but also aims at discussing evaluation structure which is the mutual influence between one criteria and the other. Through using ISM approach to give a better understanding of a system structure and draws up a useful guideline in generating a graphical representation of the structure. Herewith the essential analysis results and discussions of ISM, and ANP are elaborated as below.

Firstly, via the result of ISM analysis, it could be seen that Quality capability, Flexible capability, Technological and Service capability were mutually interrelated. This can be seen from the double-sided arrows among the four criteria in Figure 1. The diagraph 
obtained through ISM helps the $3 \mathrm{C}$ industry managers and suppliers to critically investigate each criteria and its influence thus helps them to improve the strategies for criteria. Moreover, the Environment management capability was independent from other criteria.

Secondly, what factors management should stress more in the supplier selection of $3 \mathrm{C}$ industry should be understood so that more effort can be put on improving the priorities of these factors and on evaluating suppliers. The priority/weight values of the criteria, it can be observed from Table 8 that Quality capability (Q) (0.3799) is the most important criterion for supplier selection, followed by Technological capability (T) (0.26551), Flexible capability (D) (0.23215) and Service capability (S) (0.1214) by ANP. The result shows the quality capability of supplier is the major concern of the Taiwan's $3 \mathrm{C}$ industry. It's also an important message to the $3 \mathrm{C}$ industry that if they want to win the business, the Quality capability of supplier related operations need to be enhanced.

Finally, the priorities of the sub-criteria also are listed in Table 8. In the Flexible capability category, the Process flexibility (F2) (0.46522) was rated as the most important criterion; in Quality capability category, Product quality (Q1) (0.55700) was rated as the most important; in Technical capability category, Entrepreneurial innovation capability (T1) (0.54865) was rated as the most important; and in Service capability category, Conflict / problem solving capability (S1) (0.56692) was rated as the most important. It should be emphasized again that the proposed hybrid model is capable of handling such interdependencies.

\section{Conclusions}

This study has contributed to, in particular, the supplier selection literature by: (i) proposing a research framework that relates determinants to supplier selection for $3 \mathrm{C}$ industry, (ii) developing valid and reliable measures for the dimensions based on expert's qualitative opinion, and (iii) developing a supplier selection hierarchical analytical structure to evaluate the factors in supplier selection using ISM and ANP. In practical supplier selection problems, vast amounts of criteria and attributes are typically interactive and interdependent and with elusive qualitative information. This study developed an effective evaluation framework to evaluate the factors in supplier selection for $3 \mathrm{C}$ industry. In this paper, we propose a hybrid model combining ISM and ANP, wherein ISM is to construct the complex network relationship, and ANP is to simultaneously consider the relationships of feedback and dependence of criteria in 3C industry for the case Taiwanese. Moreover, the ANP can be used not only as a way to handle the inner dependences within a set of criteria/ attributes, but also as a way of producing more valuable information for decision-making. The case study shows that decision-makers are able to capture a fairly complete picture of supplier selection while assessing the priorities of the criteria developed, validated, and operationalized by the proposed approach.

Although the present model proves valuable, there are still some areas for further development. This study builds a supplier selection model by applying five criteria however, the interrelationship among Environmental management capability and other criteria 
were not very significant. Moreover, it is suggested that future study could develop a richer, multi-hierarchical structure that incorporates other criteria/ sub-criteria with quantitative and qualitative measurement. Other analytical techniques (e.g., Decision Making Trial and Evaluation Laboratory, fuzzy integral) can be employed to solve the interactive and feedback relationships between the factors and to further explore the relative importance among the factors.

\section{References}

Agarwal, P.; Sahai, M.; Mishra, V.; Bag, M.; Singh, V. 2011. A review of multi-criteria decision making techniques for supplier evaluation and selection, International Journal of Industrial Engineering Computations 2: 801-810. http://dx.doi.org/10.5267/j.ijiec.2011.06.004

Boer, L. D.; Labro, E.; Morlacchi, P. 2001. A review of methods supporting supplier selection, European Journal of Purchasing \& Supply Management 7: 75-89.

http://dx.doi.org/10.1016/S0969-7012(00)00028-9

Chen, S.; Chen, R. 1998. Manufacturer-supplier relationship in JIT environment: IT purchasing and supply in Chinese automobile industry, Journal of Industrial Engineering and Engineering Management 12: 46-52.

Chen, C. T.; Lin, C. T.; Huang, S. F. 2006. A fuzzy approach for suppler evaluation and selection in supply chain management, International Journal of Production Economics 102: 289-301. http://dx.doi.org/10.1016/j.ijpe.2005.03.009

Dou, Y.; Zhu, Q.; Sarkis, J. 2013. Evaluating green supplier development programs with a greyanalytical network process-based methodology, European Journal of Operational Research 233(2): 420-431. http://dx.doi.org/10.1016/j.ejor.2013.03.004 .

Dulmin, R.; Mininno, V. 2003. Supplier selection using a multi-criteria decision aided method, Journal of Purchasing and Supply Management 9: 177-187.

http://dx.doi.org/10.1016/S1478-4092(03)00032-3

Evans, H.; Johnson, J. 2005. 10 Steps toward RoHS directive compliance, Circuits Assembly 16(2): 68-70.

Gosling, J.; Purvis, L.; Naim, M. M. 2010. Supply chain flexibility as a determinant of supplier selection, International Journal of Production Economics 128(1): 11-21.

http://dx.doi.org/10.1016/j.ijpe.2009.08.029

Handfield, R. B.; Walton, S. V.; Sroufe, R.; Melynyk, S. A. 2002. Applying environmental criteria to supplier assessment: a study in the application of the analytical hierarchy process, European Journal of Operational Research 141: 70-87. http://dx.doi.org/10.1016/S0377-2217(01)00261-2 Ho, W.; Xu, X.; Dey, P. K. 2010. Multi-criteria decision making approaches for supplier evaluation and selection: a literature review, European Journal of Operational Research 202: 16-24. http://dx.doi.org/10.1016/j.ejor.2009.05.009

Hsu, C. C.; Liou, J. J. H. 2013. An outsourcing provider decision model for the airline industry, Journal of Air Transport Management 28: 40-46.

http://dx.doi.org/10.1016/j.jairtraman.2012.12.009

Huang, J. J.; Tzeng, G. H.; Ong, C. S. 2005. Multidimensional data in multidimensional scaling using the analytic network process, Pattern Recognition Letters 26: 755-767.

http://dx.doi.org/10.1016/j.patrec.2004.09.027

Humphreysa, P. K.; Wong, Y. K.; Chan, F. T. S. 2003. Integrating environmental criteria into the supplier selection process, Journal of Materials Processing Technology 138: 349-356.

http://dx.doi.org/10.1016/S0924-0136(03)00097-9 
Karpak, B.; Kumcu, E.; Kasuganti, R. R. 2001. Purchasing materials in the supply chain: managing a multi-objective task, European Journal of Purchasing \& Supply Management 7: 209-216. http://dx.doi.org/10.1016/S0969-7012(01)00002-8

$\mathrm{Ku}$, C. Y.; Chang, C. T.; Ho. H. P. 2010. Global supplier selection using fuzzy analytic hierarchy process and fuzzy goal programming, Quality \& Quantity 44(4): 623-640.

http://dx.doi.org/10.1007/s11135-009-9223-1

Lamming, R.; Hampson, J. 1996. The environment as a supply chain management issue, British Journal of Management 7: 45-62. http://dx.doi.org/10.1111/j.1467-8551.1996.tb00147.x

Liao, C. N.: Kao, H. P. 2011. An integrated fuzzy TOPSIS and MCGP approach to supplier selection in supply chain management, Expert Systems with Applications 38: 10803-10811.

http://dx.doi.org/10.1016/j.eswa.2011.02.031.

Lin, H. T.; Chang, W. L. 2008. Order selection and pricing methods using flexible quantity and fuzzy approach for buyer evaluation, European Journal of Operational Research 187(2): 415-428. http://dx.doi.org/10.1016/j.ejor.2007.03.003

Liou, J. J. H.; Wang, H. S.; Hsu, C. C.; Yin S. L. 2011. A hybrid model for selection of an outsourcing provider, Applied Mathematical Modelling 35: 5121-5133.

http://dx.doi.org/10.1016/j.apm.2011.04.020

Muralidharan, C.; Anantharaman, N.; Deshmukh, S. G. 2002. A multi-criteria group decision making model for supplier rating, Journal of Supply Chain Management 38(4): 22-33.

http://dx.doi.org/10.1111/j.1745-493X.2002.tb00140.x

Ndubisi, N. O.; Jantan, M.; Hing, L. C.; Ayub, M. S. 2005. Supplier selection and management strategies and manufacturing flexibility, Journal of Enterprise Information Management 18(3): 330-349. http://dx.doi.org/10.1108/17410390510592003

Petroni, A.; Braglia, M, 2000. Vendor selection using principal component analysis, Journal of Supply Chain Management 36(2): 63-69. http://dx.doi.org/10.1111/j.1745-493X.2000.tb00078.x

Rao, P. 2002. Greening the supply chain a new initiative in south East Asia. International Journal of Operations \& Production Management 22: 632-655.

http://dx.doi.org/10.1108/01443570210427668

Sage, A. P. 1977. Interpretive structural modeling: methodology for large-scale systems. New York: McGraw-Hill.

Saaty, T. L. 1980. The analytic hierarchy process. New York: McGraw-Hill.

Saaty, T. L. 1996. Decision making with dependence and feedback: the analytic network process. Pittsburgh: RWS Publications.

Saaty, T. L. 2009. Principia mathematica decernendi: mathematical principles of decision making. Pittsburgh: RWS Publications.

Schiele, H. 2006. How to distinguish innovative suppliers? Identifying innovative suppliers as new task for purchasing, Industrial Marketing Management 35: 925-935.

http://dx.doi.org/10.1016/j.indmarman.2006.05.003

Srivastava, S. K. 2007. Green supply-chain management: a state-of the-art literature review. International Journal of Management Reviews 9: 53-80.

http://dx.doi.org/10.1111/j.1468-2370.2007.00202.x

Tam, M. C. Y.; Tummala, V. M. R. 2001. An application of the AHP in vendor selection of a telecommunications system, Omega 29: 171-182. http://dx.doi.org/10.1016/S0305-0483(00)00039-6

Tjader, Y.; May, J. H.; Shang, J.; Vargas, L. G.; Gao, N. 2013. Firm-level outsourcing decision making: a balanced scorecard-based analytic network process model, International Journal of Production Economics. http://dx.doi.org/10.1016/j.ijpe.2013.04.017 
Tsai, W. H.; Chou, W. C. 2009. Selecting management systems for sustainable development in SMEs: a novel hybrid model based on DEMATEL, ANP, and ZOGP, Expert Systems with Applications 36: 1444-1458. http://dx.doi.org/10.1016/j.eswa.2007.11.058

Tzeng, G. H.; Chiang, C. H.; Li, C. W. 2007. Evaluating intertwined effects in e-learning programs: a novel hybrid MCDM model based on factor analysis and DEMATEL, Expert Systems with Applications 32: 1028-1044. http://dx.doi.org/10.1016/j.eswa.2006.02.004

Wagner, S. M. 2009. Getting innovation from suppliers, Research-Technology Management 52(1): 8-9.

Warfield, J. N. 1974. Developing interconnection matrices in structural modeling, IEEE Transcations on Systems. Man and Cybernetics 4: 81-87. http://dx.doi.org/10.1109/TSMC.1974.5408524

Warfield, J. N. 1974. Toward interpretation of complex structural modeling, IEEE Transcations on Systems. Man and Cybernetics 4: 405-417. http://dx.doi.org/10.1109/TSMC.1974.4309336

Warfield, J. N. 1976. Societal systems: planning, policy, and complexity. New York: Wiley.

Weber, C. A.; Current, J. R.; Benton, W. C. 1991. Vendor selection criteria and methods, European Journal Operational Research 50(1): 2-18. http://dx.doi.org/10.1016/0377-2217(91)90033-R

Kwo-Liang CHEN is an Assistant Professor in the Department of Industrial Engineering and Management, China University of Science and Technology, Taiwan. He received his $\mathrm{PhD}$ degree in Institute of Business and Management, from National Chiao Tung University, Taiwan. He is a director of information technology division in the Small and Medium Enterprise Administration (MOEA) in Taiwan. In particular, he is interested to research in Technology Management, Small and Medium Enterprise Policy and Knowledge Management.

Ching-Chiang YEH is currently an Associate Professor in the Department of Business Administration, National Taipei University of Business, Taiwan. He received his PhD degree in Institute of Business and Management, and MBA from National Chiao Tung University, Taiwan. His research focuses on decision science, data mining, and management of technology.

Jo-Chen HUANG is currently a Project Manager in the 3C industry, Taiwan. She received EMBA from Soochow University, Taiwan. She research focuses on supply chain management and marketing management. 